Limnological Review (2010) 10, 1: 3-14

DOI 10.2478/v10194-011-0001-9

\title{
Morphology of peatland lakes
}

\author{
Krzysztof Banaś
}

University of Gdańsk, Department of Plant Ecology, Legionów 9, 80-441 Gdańsk, Poland; e-mail: k.banas@ug.edu.pl

\begin{abstract}
The morphometric features of 10 small (0.1-2.9 ha) and shallow (4-16 m) peatland lakes, located in basins filled with peat, were examined. The elongation of such lakes and the development coefficient of their shorelines are very low. The mean depth is close to the maximum value $(7.0 \pm 4.8$ and $7.8 \pm 3.9 \mathrm{~m}$, respectively), as the lake bottom is normally flat and the basin walls are often vertical. In terms of morphometric features, the peatland lakes were divided into large (1.92 $\pm 1.12 \mathrm{ha})$ and small $(0.33 \pm 0.33 \mathrm{ha})$. The former are surrounded by a relatively narrow belt of peatlands and characterized by low values of Ohle coefficient and Schindler factor (1.81 \pm 2.04 and $0.32 \pm 0.13$ ), which makes them very susceptible to the effect of peatlands. The smallest lakes are located in the central part of big peatlands. Their values of Ohle coefficient and Schindler factor are five times higher, whereas their volume is ten times less (13 $750 \mathrm{~m}^{3}$ as compared to $125000 \mathrm{~m}^{3} ; \mathrm{p}<0.001$ ). The bottom slope angle is considerable. In peatland lakes, there is little space that could be occupied by vegetation. In deep moraine-dammed lakes plants occur only on vertical walls, whereas in shallow water bodies, plants also thrive on the bottom.
\end{abstract}

Key words: peatland lakes, lake basin morphology, shoreline, bottom shape, peat deposit

\section{Introduction}

Almost all lakes in Poland are postglacial in origin. In Pomerania (NW Poland), lake basins formed in the period of Pleistocene glaciation due to the development of ground and terminal moraines and as a result of the effect of runoff waters flowing from the melting continental ice-sheet. At that time, lakes underwent numerous transformations, mainly due to the increased accumulation of the mineral matter carried by snow-melt waters. The size and shape of the lake basins depend on the processes that derive in their formation. The elongated and deep basins of ribbon lakes were produced as the substratum was eroded by waters flowing under the ice-sheet, whereas the shallow and oval basins of thaw lakes formed as a result of the slow melting ice blocks covered with postglacial deposits. After the climate warmed, and as a result of vegetation development, organic matter began to play an increasingly important role in the shaping of lake basins. In geologically young water bodies, especially the sedimentation matter was of importance. As lake basins became shallower, sedentation began to play an increasingly more important role in the sedimentation processes (Tobolski 2000).
The morphometric features of lake basins have a decisive effect on the functioning of an entire ecosystem (Hutchinson 1957; Kajak 1998). They influence the way water mixes and determine the waters physical (optical and thermal qualities) and chemical (content of gases, mineral and organic substances) properties in individual layers (epi-, meta- and hypolimnion), as well as regulate the development occurrence of plants and animals at the same time (Hutchinson 1957).

Almost half of Polish lakes are situated in the Pomerania region (48\%; Choiński 2006). A considerable fraction of these water bodies comprises small and shallow softwater lakes. They are located on acid and poor soils occupied by pine forests and beech woods. Low water and sediment $\mathrm{pH}$ as well as low content of mineral substances in the substratum are typical of the environmental conditions in these water bodies. Submerged vegetation is sparse: isoetids dominate in the shallow littoral (Szmeja et al. 1997); deeper bryophytes, mainly peatmosses (Gos et al. 1998; Banaś and Gos 1998; Gos and Banaś 1999). The ombrogenous bog is one of the final transformations of such an ecosystem. In the Pomerania region more than half of all the peatlands originated in this way; which is proved, by the presence of gyttja in the substrata of lake basins (Tobolski 2000). 
The initial overgrowth phases of acid lakes are connected with the development of poor fen communities on their margins. Over time, the communities resemble a typical raised bog and consist mainly of peat mosses. Due to the presence of other wetland plants which can grow in the depths, a peatmoss mat, which floats on the surface and is a characteristic element of peatland lake vegetation, is formed. Then the lake basin is in large measure filled with peat. In peatlands, water bodies generally have a central location and are characterized by very low overgrowth dynamics (Kowalewski and Tobolski 1997; Timmermann 1998; Kowalewski 2003; Kowalewski and Milecka 2003).

In lake-mire complexes, environmental conditions (Shotyk 1988) and peatland vegetation are rather accurately described; however, there are individual data on the morphometry of such water bodies (Turczyński et al. 2009) or their submerged vegetation (Banaś and Gos 2008). The aim of this work is to determine the morphometry and the main factors differentiating peatland lakes in NW Poland.

\section{Methods}

The study was conducted from 2004 to 2006 in the Pomeranian Lakeland (NW Poland) in 10 peat- land lakes (Fig. 1), that is ones surrounded by a belt of poor fens and/or raised bogs. In order to determine the effect of peatlands on a lake, modified Ohle $\left(\mathrm{C}_{\mathrm{O}}\right)$ and Schindler $\left(\mathrm{C}_{\mathrm{S}}\right)$ coefficients, where peatland area was used instead of catchment area, were calculated. The length (l) and maximum breadth (b) of lakes, as well as their surface area $\left(A_{L}\right)$ and peatland area $\left(A_{p}\right)$, were measured on the basis of a map with a scale of $1: 10,000$, while the maximum depth $\left(\mathrm{z}_{\max }\right)$ was determined using a NEXUS DEPTH echo sounder. Lake elongation $(\mathrm{W})$ was calculated from the formula $\mathrm{W}=\mathrm{l} / \mathrm{b}$, and shoreline development $\left(D_{L}\right)$ as $L / 2 \sqrt{ }(\pi P)$, where $L$ stands for shoreline length [m] (Wetzel 2001). What is more, mean depth $(z)$, relative depth $\left(z_{r}=50 z_{\text {max }} \sqrt{ } \pi / \sqrt{ } A\right)$, depth coefficient $\left(C_{z}\right)$, mean breadth $\left(b=A_{L} / l\right)$, level of basin concavity $\left(E=\left(3 z-z_{\max }\right) / z_{\max } \cdot 100 \%\right)$, bottom area $\left(A_{B}\right)$, mean basin slope inclination $(N)$ and lake volume

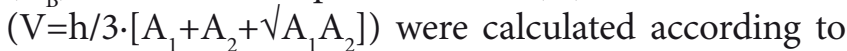
formulas suggested by Lange (1993). No bathymetric charts were drawn for the studied lakes. The data necessary for the calculations above were obtained from field measurements which consisted in the determination of changes in bottom shape along the depth gradient. On account of vertical peat walls and numerous hollows in them, a scuba diver carried out the measurements, recording the distance from a vertically anchored tape to lake bottom every $0.5 \mathrm{~m}(1 \mathrm{~m})$ of depth.

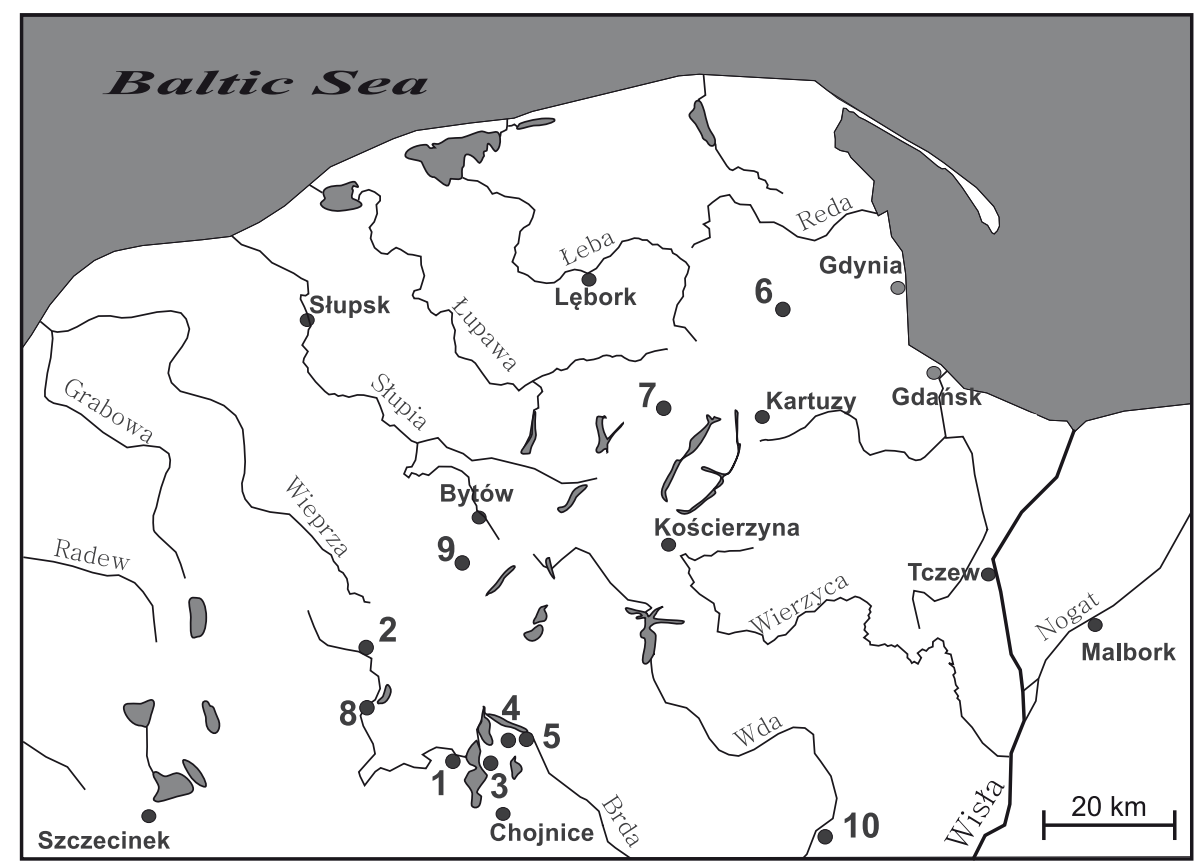

Fig. 1. Location of lakes: 1 - Małe Łowne, 2 - Zahebowe, 3 - Rybie Oko, 4 - Kocioł, 5 - Męcikał, 6 - nameless lake near Szemud, 7 Żurawie Chrusty, 8 - Kumki Małe, 9 - nameless lake near Leniwe, 10 - Dury Południowe 
The statistical analysis consisted in the calculation of the arithmetic mean (x), standard deviation (s.d.), as well as range (min.-max.) and median (Me) of features (Hays 1988). Principal Components Analysis (PCA) was performed in the program CANOCO 4.5 (ter Braak and Smilauer 1998). The lakes were grouped by means of Ward's method using the urban distance (Manhattan) in the program Statistica 7.1.

\section{Results}

\section{Morphology of lake basins}

Peatland lake area is small $(0.96 \pm 1.07$ ha; $\mathrm{Me}=0.48$ ), does not exceed 3 ha and is smaller than 0.3 ha in the case of half of the water bodies (Table $1)$. The peatland area is usually larger than that of a lake $(1.87 \pm 1.15$ ha; $\mathrm{Me}=1.44)$ and peatlands with very small water bodies have the biggest area (Fig. 2). The ratio between peatland area and lake area is described by Ohle coefficient. Its highest values were recorded in the smallest lakes (Table 1). It is worth mentioning that these values change within a very wide range (0.3-30.8). On the other hand, Schindler coefficient is less variable, but also in its case the highest values were noted for the same smallest lakes, which proves that they are highly susceptible to influences from peatlands.

Lake length varies from $36 \mathrm{~m}$ to $274 \mathrm{~m}$, and the maximum breadth from $28 \mathrm{~m}$ to $165 \mathrm{~m}$. The mean breadth is only a little narrower than the maximum (61 $\pm 35 \mathrm{~m}$ and $78 \pm 46 \mathrm{~m}$, respectively). Lake elongation is small ( $1.53 \pm 0.41 ; \mathrm{Me}=1.4)$, and only in the case of two water bodies slightly exceeds 2.0. The mean shoreline length is $334 \pm 215 \mathrm{~m} ; \mathrm{Me}=260$, and the coefficient of its development slightly exceeds $1.09 \pm 0.07$, which shows that the shape of most of these lakes is close to circular.

Peatland lakes are not very deep (7.8 \pm 3.9 ; $\mathrm{Me}=6.8$ ), but water bodies which are a dozen or so metres deep also occur among them (Table 1). The mean depth is difficult to measure even if the ratio between lake volume and water table suggested by Lange (1993) is found. It may happen that the mean depth ( $\mathrm{z}$ ) obtained in the above-mentioned way is greater than the maximum depth $\left(\mathrm{z}_{\max }\right)$, but in fact it is only very close to the maximum (Table 1). This results from an untypical bottom shape of peatland lakes in relation

Table 1. Features and morphometric coefficients of lake basins: $A_{L}$ - lake area; $A_{P}$ - peatland area; $C_{O}-$ modified Ohle coefficient; $C_{S}-$ Schindler factor; $\mathrm{W}$ - lake elongation; 1 - maximum length; $\mathrm{b}_{\max }$ - maximum breadth; $\mathrm{b}$ - mean breadth; $\mathrm{L}-$ shore line; $\mathrm{D}_{\mathrm{L}}-$ shoreline development; $\mathrm{z}_{\max }$ - maximum depth; $\mathrm{z}$ - mean depth; $\mathrm{z}_{\mathrm{r}}$ - relative depth; $\mathrm{C} \mathrm{z}$ - depth coefficient; $\mathrm{V}$ - volume; $\mathrm{E}$ - level of basin concavity; $\mathrm{A}_{\mathrm{B}}$ - bottom area; $\mathrm{N}$ - mean basin slope inclination.

\begin{tabular}{|c|c|c|c|c|c|c|c|c|c|c|c|c|c|c|c|c|c|c|}
\hline $\mathrm{Nr}$ & $\begin{array}{c}\mathrm{A}_{\mathrm{L}} \\
\text { [ha] }\end{array}$ & $\begin{array}{c}\mathrm{A}_{\mathrm{p}} \\
\text { [ha] }\end{array}$ & $C_{0}$ & $\mathrm{C}_{\mathrm{s}}$ & W & $\begin{array}{c}\text { I } \\
{[\mathrm{m}]}\end{array}$ & $\begin{array}{l}\mathrm{b}_{\max } \\
{[\mathrm{m}]}\end{array}$ & $\begin{array}{c}\mathrm{b} \\
{[\mathrm{m}]}\end{array}$ & $\begin{array}{c}\mathrm{L} \\
{[\mathrm{m}]}\end{array}$ & $D_{L}$ & $\begin{array}{l}z_{\max } \\
{[\mathrm{m}]}\end{array}$ & $\begin{array}{c}\mathrm{z} \\
{[\mathrm{m}]}\end{array}$ & $\begin{array}{c}z_{r} \\
{[\mathrm{~m}]}\end{array}$ & $\mathrm{Cz}$ & $\underset{\left[\mathrm{m}^{3}\right]}{\mathrm{V}}$ & $\begin{array}{c}E \\
{[\%]}\end{array}$ & $\begin{array}{c}A_{B} \\
{\left[m^{2}\right]}\end{array}$ & $\mathrm{N}$ \\
\hline 1 & 2.917 & 3.620 & 1.241 & 0.493 & 2.07 & 274 & 133 & 107 & 741.8 & 1.23 & 6.0 & 4.5 & 0.035 & 0.757 & 132519 & 127.1 & 29317.2 & 0.062 \\
\hline 2 & 0.298 & 0.661 & 2.222 & 0.824 & 2.34 & 88 & 37 & 34 & 225.4 & 1.17 & 4.0 & 3.9 & 0.073 & 0.977 & 11633 & 193.1 & 3081.4 & 0.130 \\
\hline 3 & 0.281 & 1.425 & 5.068 & 1.291 & 1.71 & 84 & 49 & 34 & 215.2 & 1.14 & 6.0 & 4.7 & 0.113 & 0.784 & 13219 & 135.1 & 2972.2 & 0.201 \\
\hline 4 & 2.797 & 0.910 & 0.325 & 0.288 & 1.42 & 235 & 165 & 119 & 647.5 & 1.09 & 7.5 & 4.6 & 0.045 & 0.614 & 128889 & 84.3 & 28111.4 & 0.079 \\
\hline 5 & 0.171 & 3.120 & 18.219 & 5.732 & 1.39 & 56 & 41 & 30 & 168.0 & 1.15 & 4.0 & 3.4 & 0.097 & 0.838 & 5743 & 151.5 & 1791.5 & 0.171 \\
\hline 6 & 0.167 & 0.596 & 3.577 & 0.853 & 1.09 & 47 & 43 & 35 & 145.5 & 1.01 & 7.8 & 5.4 & 0.191 & 0.688 & 8949 & 106.5 & 1870.8 & 0.339 \\
\hline 7 & 0.665 & 3.200 & 4.813 & 0.350 & 1.09 & 92 & 85 & 72 & 295.1 & 1.02 & 16.0 & 16.6 & 0.196 & 1.039 & 110567 & 211.8 & 8118.7 & 0.348 \\
\hline 8 & 1.279 & 1.088 & 0.851 & 0.183 & 1.61 & 163 & 101 & 78 & 430.3 & 1.07 & 10.5 & 10.1 & 0.093 & 0.963 & 129222 & 188.8 & 13444.4 & 0.165 \\
\hline 9 & 0.084 & 2.593 & 30.772 & 2.290 & 1.27 & 36 & 28 & 23 & 106.6 & 1.04 & 11.7 & 13.9 & 0.403 & 1.186 & 11690 & 255.7 & 1191.8 & 0.714 \\
\hline 10 & 0.985 & 1.456 & 1.478 & 0.781 & 1.31 & 123 & 94 & 80 & 362.7 & 1.03 & 4.0 & 3.2 & 0.040 & 0.793 & 31267 & 138.0 & 9924.3 & 0.071 \\
\hline Mean & 0.964 & 1.867 & 6.857 & 1.308 & 1.53 & 120 & 78 & 61 & 333.8 & 1.09 & 7.8 & 7.0 & 0.129 & 0.864 & 58370 & 159.2 & 9982.4 & 0.228 \\
\hline SD & 1.070 & 1.150 & 9.887 & 1.671 & 0.41 & 80 & 46 & 35 & 215.2 & 0.07 & 3.9 & 4.8 & 0.112 & 0.174 & 58275 & 52.3 & 10671.3 & 0.199 \\
\hline Median & 0.481 & 1.441 & 2.899 & 0.803 & 1.40 & 90 & 67 & 54 & 260.2 & 1.08 & 6.8 & 4.7 & 0.095 & 0.816 & 22243 & 144.7 & 5600.0 & 0.168 \\
\hline Min. & 0.084 & 0.596 & 0.325 & 0.183 & 1.09 & 36 & 28 & 23 & 106.6 & 1.01 & 4.0 & 3.2 & 0.035 & 0.614 & 5743 & 84.3 & 1191.8 & 0.062 \\
\hline Max. & 2.917 & 3.620 & 30.772 & 5.732 & 2.34 & 274 & 165 & 119 & 741.8 & 1.23 & 16.0 & 16.6 & 0.403 & 1.186 & 132519 & 255.7 & 29317.2 & 0.714 \\
\hline
\end{tabular}


to basins of lakes not located in peatlands. Above all, this concerns the presence of water 'pockets' not only under the floating mat moving onto the surface of the water body, but mainly under the katotelm, where a considerable amount of water is trapped (Fig. 3). The unusual topography of the organic bottom in peatland lakes causes them to have a very high volume and small surface area at the same time. Their volume is greater than that of lakes whose basins are mineral and resemble reversed truncated cones.

The concavity coefficient of form always has a high positive value (159.2 \pm 52.3 ; $\mathrm{Me}=144.7$; Table 1), which indicates very high concavity of a basin. The volume of peatland lakes is too high to be contained in cone volume, which is typical of most water bodies. It is even higher than the volume of a cylinder whose base equals the area of the lake. The volume is mainly greater by virtue of the water under the floating mat gradually covering the water table and the space in the pockets under the katotelm (Fig. 3). The floating mat is not included in the water table area since it belongs to the living part of the peatland (acrotelm). The floating mat is 1-3 m wide. Assuming that the volume of a water body is calculated as the volume of a cylinder, and $\mathrm{z}$ equals $\mathrm{z}_{\max }$ (which is a minor error), the volume in the entire water column only under the floating mat (1-3 m in breadth) is between 10 and $30 \%$ of the lake volume. The underestimation of the volume is actually even greater due to the presence of pockets in the katotelm (Fig. 3).
Peatland lake volume is higher than that of lakes not located in peatlands. In the group of peatland lakes the range of this feature is great $\left(5,743-132,519 \mathrm{~m}^{3}\right.$; $\mathrm{Me}=22,243)$. The volume depends predominantly on the area and depth of a water body (Table 1). Bottom area, which is determined by the basin slope inclination when the water table has a certain area, is characterized by an equally high variability $(F=9,981 \pm 10,671$ $\mathrm{m}^{2} ; \mathrm{Me}=5,600$ ). The highest recorded value of the coefficient of slope inclination in these lakes is 0.71 and the lowest is 0.06 . In relatively large sections the bottom descends vertically (Fig. 4), and in places even at an angle of over $90^{\circ}$, forming overhangs of the katotelm. Below the slope the bottom descends slightly and then is flat in a considerable portion of the lake basin area (Fig. 4).

In shallow water bodies, whose waters generally mix to their bottom and wave action is high, the floating mat is most often very poorly developed. In deep lakes, where water mixing and wave action are very slight, the floating mat is much better developed. Sometimes a belt of floating vegetation, which can be even $3 \mathrm{~m}$ wide and consist of mainly bryophytes is formed (Fig. 4). Such a belt limits the development of submerged plants especially because of shaded habitats both on the vertical walls of the katotelm and on the lake bottom. In such conditions, vegetation occurs only on the edge of the floating mat forming curtains that droop into the depths.

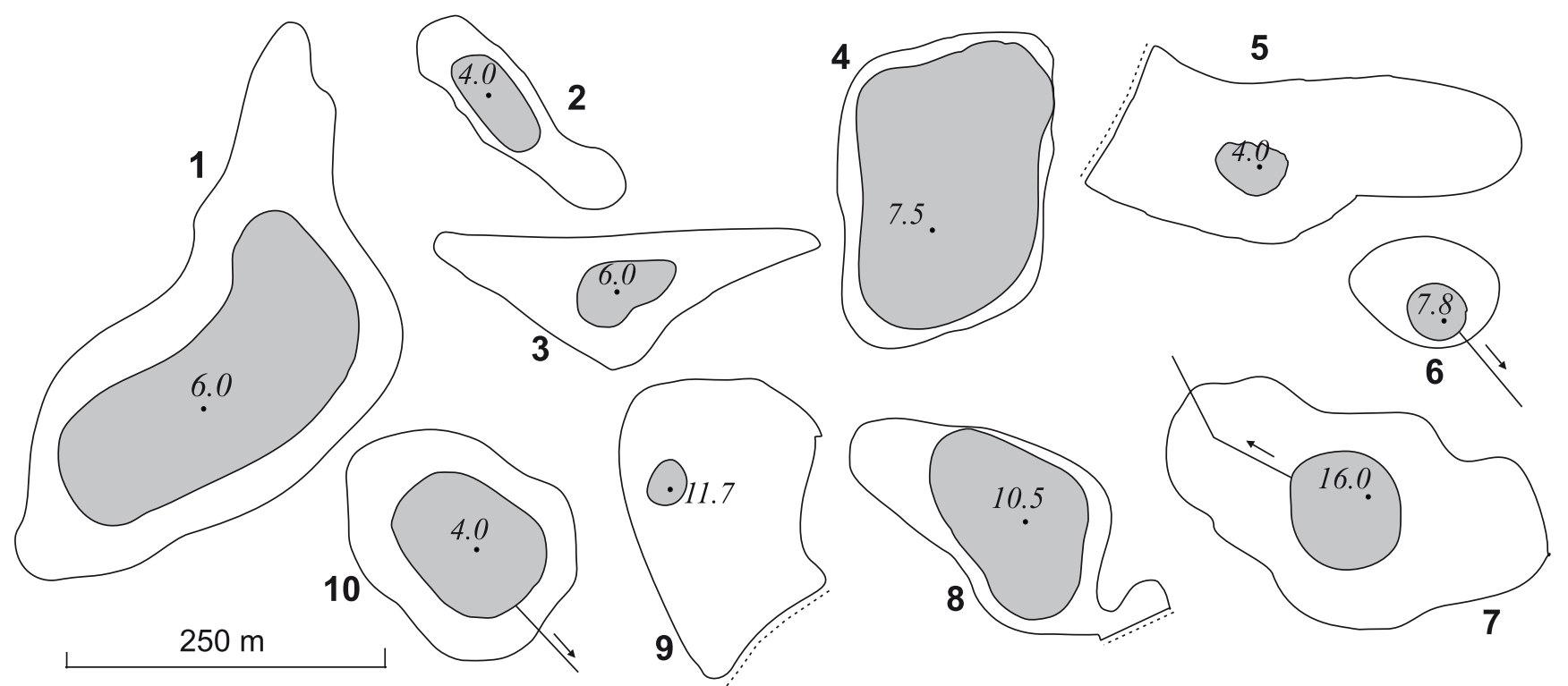

Fig. 2. Location of studied lakes (1-10) within peatlands and the situation of the deepest place. 1 - Małe Łowne, 2 - Zahebowe, 3 - Rybie Oko, 4 - Kocioł, 5 - Męcikał, 6 - nameless lake near Szemud, 7 - Żurawie Chrusty, 8 - Kumki Małe, 9 - nameless lake near Leniwe, 10 - Dury Południowe 
A
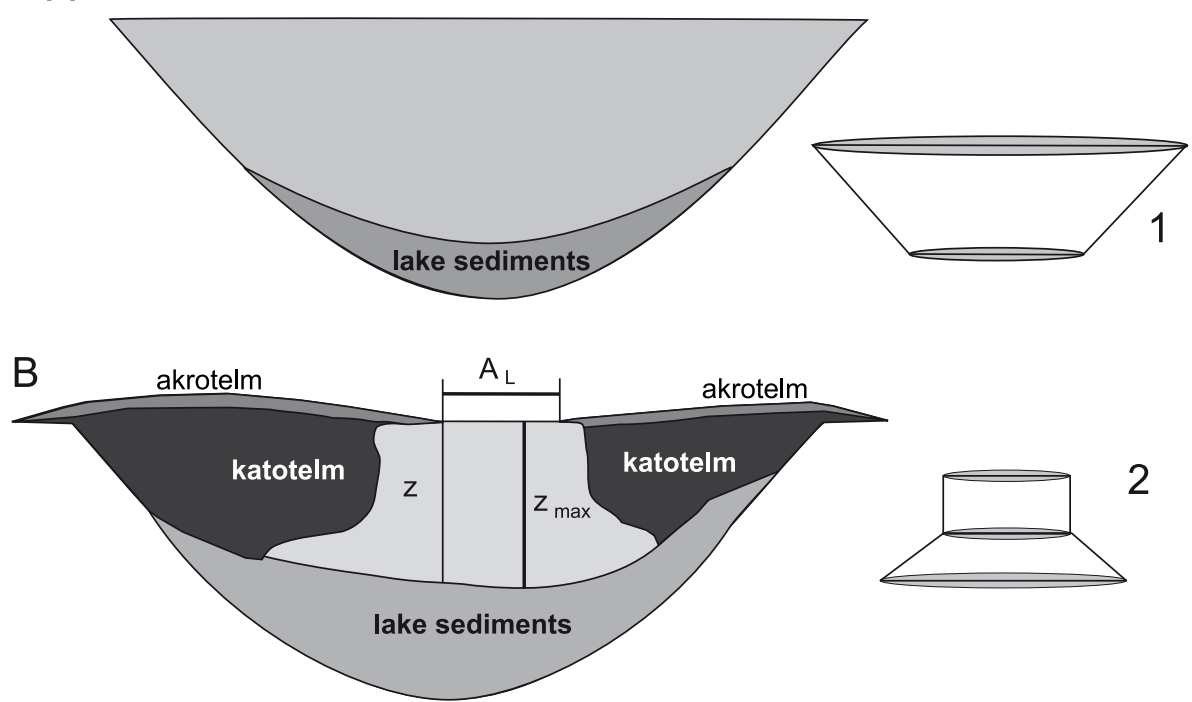

Fig. 3. Basins of lakes which are not located in peatlands (A) and peatland lakes (B) and regular solids describing their volume: 1 truncated cone, 2 - cylinder and truncated cone. $A_{L}$ - lake area; $z_{\max }$ - maximum depth; $\mathrm{z}$ - mean depth
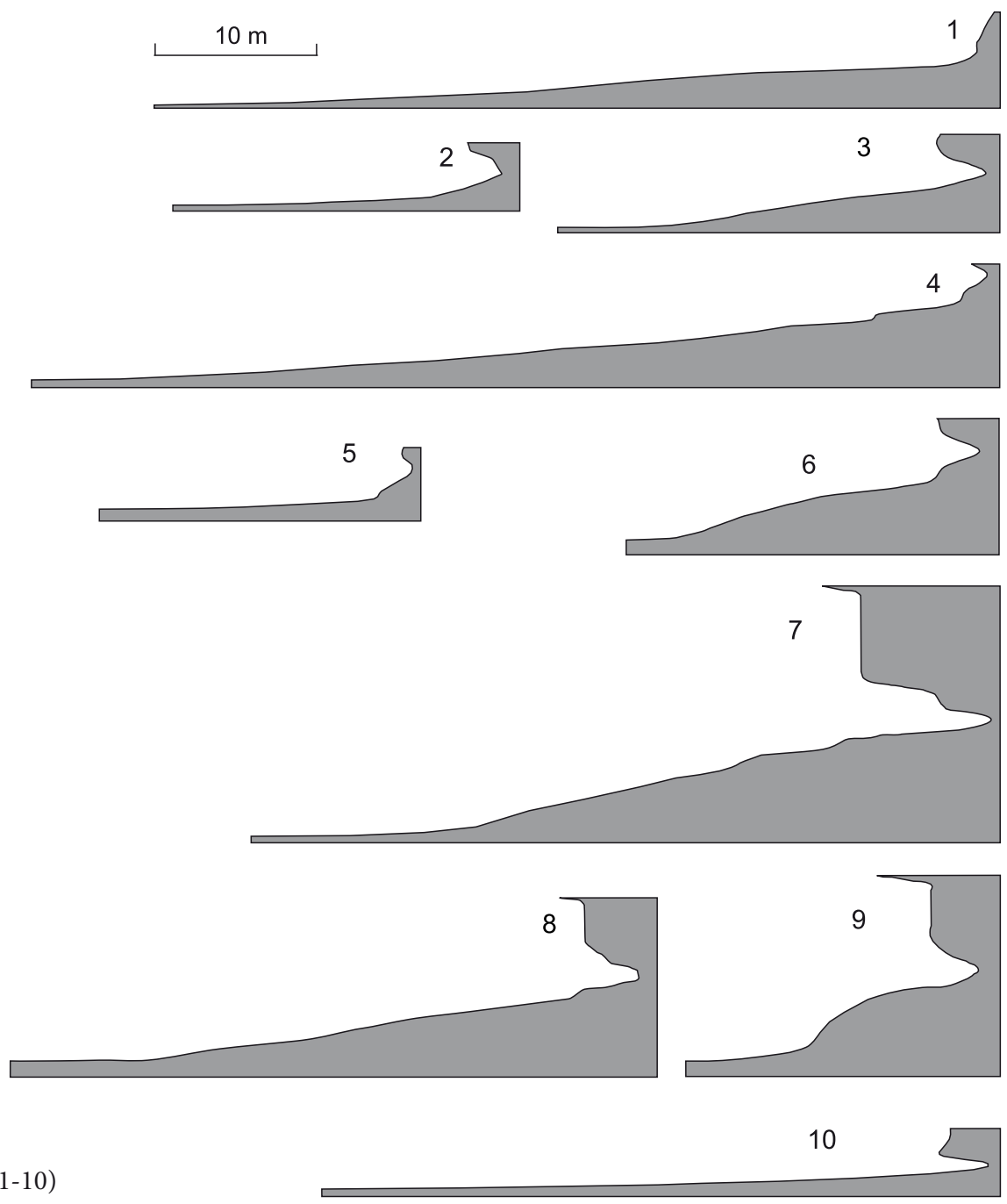


\section{Typology of lake basins}

In terms of morphometric features, peatland lakes can be divided into two groups (Fig. 5): big ones with a high volume of basins and small, not very capacious ones. It should be emphasised, though, that even the biggest peatland lakes, in comparison with the majority of other lakes, are very small, generally shallow, and located in small melt out hollows in the ground. Lake $(p=0.016)$ and bottom area $(p=0.011)$, volume $(\mathrm{p}<0.001)$, length $(\mathrm{p}=0.017)$, maximum $(\mathrm{p}=0.007)$ and mean breadth $(\mathrm{p}=0.007)$, and shoreline length $(\mathrm{p}=0.013)$ are the main morphometric features which differentiate peatland lakes in a statistically significant way.

The biggest lakes in terms of surface area (1.92 \pm 1.12 ha; $\mathrm{Me}=2.04$; Table 2) are surrounded by a relatively narrow belt of poor fens or raised bogs which mainly cover a similar area to the water body (2.21 $\pm 1.40 \mathrm{ha})$. Ohle and Schindler coefficients are low (1.81 \pm 2.04 and $0.32 \pm 0.13$, respectively), which may indicate that the influence of peatlands on the conditions in these lakes is insignificant. The elongation of lakes is inconsiderable, and their length and breadth differ only slightly (191 $\pm 80 \mathrm{~m}$ and $121 \pm 35 \mathrm{~m})$. The maximum depth is $10 \pm 4.4 \mathrm{~m}(\mathrm{Me}=9)$ and only a little greater than the mean depth $(9 \pm 5.7 \mathrm{~m} ; \mathrm{Me}=7.4)$. The volume of these water bodies ranges from $110,000 \mathrm{~m}^{3}$ to $132,000 \mathrm{~m}^{3}$, and the coefficient of bottom slope inclination from 0.06 to 0.32 . Close to the floating mat the bottom falls off vertically (often even to a depth of $3 \mathrm{~m}$ ), whereas deeper it is mainly flat.

The smallest lakes $(0.33 \pm 0.33 \mathrm{ha} ; \mathrm{Me}=0.23)$ are generally situated in the centre of peatlands, which are a few times bigger than the water bodies (1.64 \pm 1.02 ; $\mathrm{Me}=1.44$ ). Ohle and Schindler coefficients are five times as high as in the previous group. In addition, the volume of these water bodies is almost ten times smaller $\left(13,750 \mathrm{~m}^{3}\right.$ as compared to $125,000 \mathrm{~m}^{3}$; $\mathrm{p}<0.001$ ), which makes them very susceptible to the effect of peatlands. Bottom slope inclination is greatly varied ( $0.27 \pm 0.24 ; \mathrm{Me}=0.19)$, and amounts to 0.7 in the deepest lakes. The elongation of basins is low, and the same as that of big lakes, while the maximum depth is decidedly shallower $(6.25 \pm 3.1 \mathrm{~m}$; Me=5).

The principal component analysis (PCA) showed that the morphometric variation results mainly correlated with the first factorial axis, that is

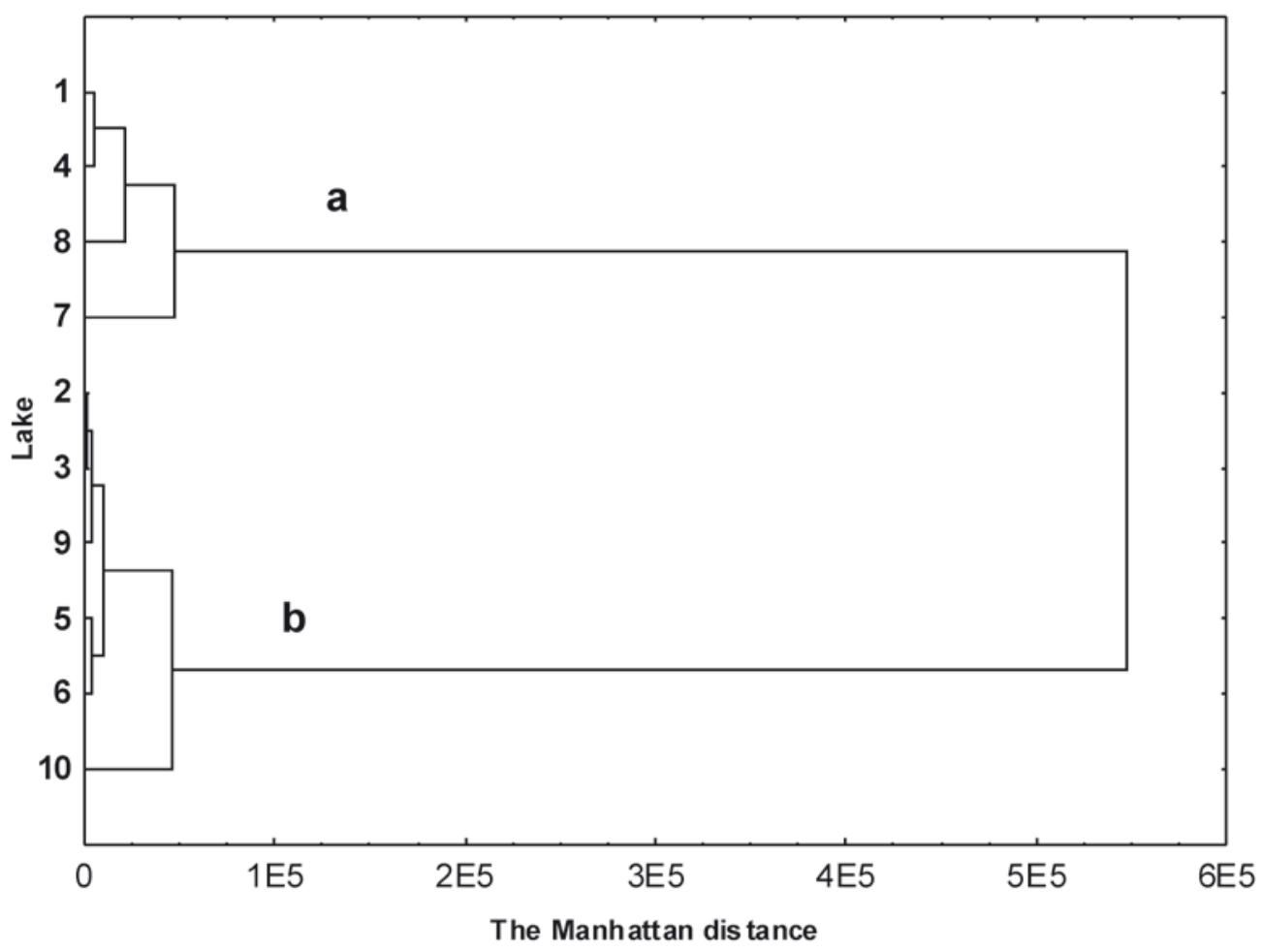

Fig. 5. Result of lake grouping (1-10), where: a - big lakes with high volume; $b$ - small lakes with small volume. Division based on: 1 , $b_{\text {max }}$ b, $A_{L}, A_{P}, z_{\max }, z, z_{r}, C z, W, D_{L}, L, E, A_{B}, N, V, C o, C s$ (see chapter Methods) 
Table 2. Features and morphometric coefficients of selected groups (a, b) of peatland lakes

\begin{tabular}{|c|c|c|c|c|c|c|}
\hline Traits & Group & Mean & Standard deviation & Median & Minimum & Maximum \\
\hline \multirow{2}{*}{$\begin{array}{c}A_{L} \\
{[h a]}\end{array}$} & a & 1.915 & 1.118 & 2.038 & 0.665 & 2.917 \\
\hline & $b$ & 0.33 & 0.330 & 0.226 & 0.084 & 0.985 \\
\hline \multirow{2}{*}{$\begin{array}{c}\mathrm{A}_{\mathrm{p}} \\
{[\mathrm{ha}]}\end{array}$} & a & 2.205 & 1.404 & 2.144 & 0.910 & 3.620 \\
\hline & $\mathrm{b}$ & 1.642 & 1.022 & 1.441 & 0.596 & 3.120 \\
\hline \multirow{2}{*}{$\mathrm{C}_{\mathrm{O}}$} & a & 1.808 & 2.039 & 1.046 & 0.325 & 4.813 \\
\hline & $b$ & 10.22 & 11.810 & 4.3225 & 1.478 & 30.772 \\
\hline \multirow[t]{2}{*}{$\mathrm{C}_{\mathrm{s}}$} & a & 0.3285 & 0.130 & 0.319 & 0.183 & 0.493 \\
\hline & $\mathrm{b}$ & 1.96 & 1.933 & 1.072 & 0.781 & 5.732 \\
\hline \multirow{2}{*}{ W } & a & 1.5475 & 0.409 & 1.515 & 1.09 & 2.07 \\
\hline & $b$ & 1.52 & 0.451 & 1.35 & 1.09 & 2.34 \\
\hline \multirow{2}{*}{$\begin{array}{c}\mathrm{I} \\
{[\mathrm{m}]}\end{array}$} & a & 191 & 80.436 & 199 & 92 & 274 \\
\hline & $\mathrm{b}$ & 72.33 & 32.179 & 70 & 36 & 123 \\
\hline \multirow{2}{*}{$\begin{array}{l}\mathrm{b}_{\max } \\
{[\mathrm{m}]}\end{array}$} & a & 121 & 35.478 & 117 & 85 & 165 \\
\hline & $\mathrm{b}$ & 48.67 & 23.278 & 42 & 28 & 94 \\
\hline \multirow{2}{*}{$\begin{array}{c}\mathrm{b} \\
{[\mathrm{m}]}\end{array}$} & $a$ & 94 & 22.613 & 92.5 & 72 & 119 \\
\hline & $\mathrm{b}$ & 39.33 & 20.412 & 34 & 23 & 80 \\
\hline \multirow{2}{*}{$\begin{array}{c}\mathrm{L} \\
{[\mathrm{m}]}\end{array}$} & a & 528.675 & 203.123 & 538.9 & 295.1 & 741.8 \\
\hline & $\mathrm{b}$ & 203.90 & 89.414 & 191.6 & 106.6 & 362.7 \\
\hline \multirow{2}{*}{$D_{L}$} & $a$ & 1.1025 & 0.090 & 1.08 & 1.02 & 1.23 \\
\hline & $\mathrm{b}$ & 1.09 & 0.071 & 1.09 & 1.01 & 1.17 \\
\hline \multirow{2}{*}{$\begin{array}{l}Z_{\max } \\
{[\mathrm{m}]}\end{array}$} & $a$ & 10 & 4.416 & 9 & 6 & 16 \\
\hline & $\mathrm{b}$ & 6.25 & 3.077 & 5 & 4 & 11.7 \\
\hline \multirow{2}{*}{$\begin{array}{c}\mathrm{z} \\
{[\mathrm{m}]}\end{array}$} & $a$ & 8.95 & 5.732 & 7.35 & 4.5 & 16.6 \\
\hline & $b$ & 5.75 & 4.077 & 4.3 & 3.2 & 13.9 \\
\hline \multirow{2}{*}{$\begin{array}{c}z_{r} \\
{[\mathrm{~m}]}\end{array}$} & a & 0.09225 & 0.074 & 0.069 & 0.035 & 0.196 \\
\hline & $\mathrm{b}$ & 0.15 & 0.133 & 0.105 & 0.04 & 0.403 \\
\hline \multirow{2}{*}{$\mathrm{C}_{\mathrm{z}}$} & $a$ & 0.84325 & 0.194 & 0.86 & 0.614 & 1.039 \\
\hline & $\mathrm{b}$ & 0.88 & 0.178 & 0.8155 & 0.688 & 1.186 \\
\hline \multirow{2}{*}{$\underset{\left[\mathrm{m}^{3}\right]}{\mathrm{V}}$} & a & 125299.3 & 9957.213 & 129055.5 & 110567 & 132519 \\
\hline & $b$ & 13750.17 & 8977.908 & 11661.5 & 5743 & 31267 \\
\hline \multirow{2}{*}{$\begin{array}{c}E \\
{[\%]}\end{array}$} & a & 153 & 58.108 & 157.95 & 84.3 & 211.8 \\
\hline & $b$ & 163.32 & 53.342 & 144.75 & 106.5 & 255.7 \\
\hline \multirow{2}{*}{$\begin{array}{c}A_{B} \\
{\left[m^{2}\right]}\end{array}$} & a & 19747.93 & 10590.751 & 20777.9 & 8118.7 & 29317.2 \\
\hline & $\mathrm{b}$ & 3472.00 & 3244.126 & 2421.5 & 1191.8 & 9924.3 \\
\hline \multirow{2}{*}{$\mathrm{N}$} & $\mathrm{a}$ & 0.1635 & 0.131 & 0.122 & 0.062 & 0.348 \\
\hline & $b$ & 0.27 & 0.235 & 0.186 & 0.071 & 0.714 \\
\hline
\end{tabular}




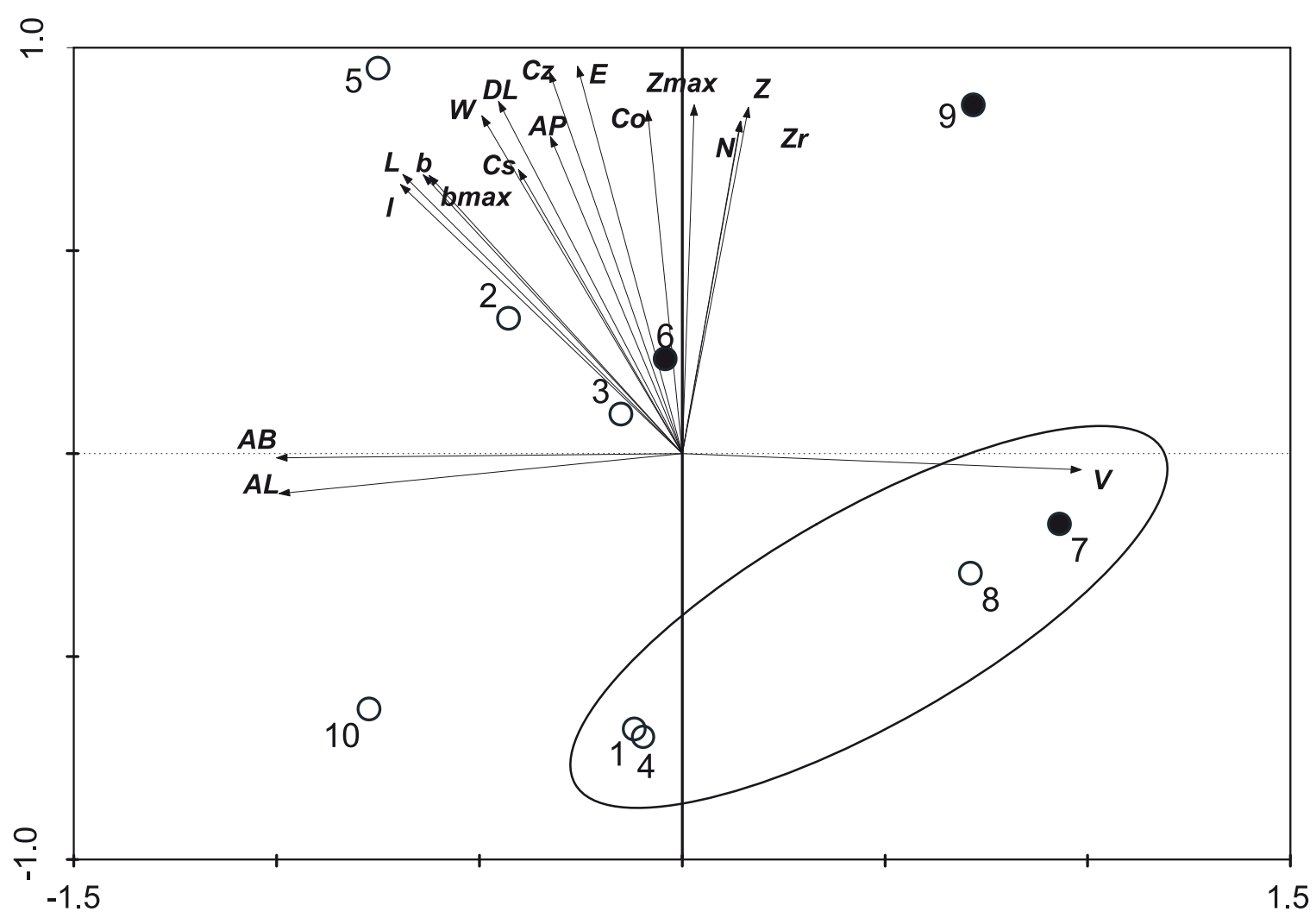

Fig. 6. Features and morphometric coefficients differentiating big $(1,4,7,8)$ and small lakes on outwash plains (white circles) and in moraine areas (black circles)

lake and bottom area and lake volume. The remaining features and coefficients of lake basins have a similar, but more limited, effect on the distribution of the studied objects in the factorial space (Fig. 6). Furthermore, lakes located on moraines are in one part of the factorial space, which suggests that they differ in terms of morphometric features from the ones occurring on outwash plains.

\section{Basins of moraine-dammed and outwash lakes}

Lakes situated in a moraine landscape (no. 6, 7 and 9; see Fig. 1) are characterised by a small area (0.31 \pm 0.31 ha; $\mathrm{Me}=0.17$ ), whereas peatlands which surround them are almost seven times as big (2.13 \pm 1.36 ha; $\mathrm{Me}=2.59$ ). The high value of Ohle coefficient $(13.0 \pm 15.4 ; \mathrm{Me}=4.8)$ shows that the lakes are very susceptible to the effect of peatlands. They have virtually equal length and breadth $(58 \pm 30 \mathrm{~m}$ and $52 \pm 30$ $\mathrm{m}$, respectively) and a very low coefficient of shoreline development $(1.15 \pm 0.10 ; \mathrm{Me}=1.09)$, and are only slightly elongated $(1.15 \pm 0.10 ; \mathrm{Me}=1.09)$, which means that they are circular in shape. The maximum depth of moraine-dammed lakes is considerable $(11.8 \pm 4.1 \mathrm{~m}$;
$\mathrm{Me}=11.7)$ and similar to the mean depth. The coefficient of depth is close to one (Fig. 7). The coefficient of basin concavity is very high $(191.3 \pm 76.7 ; \mathrm{Me}=211.8)$. Lake volume is small and very variable $(8,949-110,567$ $\left.\mathrm{m}^{3} ; \mathrm{Me}=11,69\right)$, for example the bottom area $(1,192$ $\left.8,119 \mathrm{~m}^{2} ; \mathrm{Me}=1,871\right)$. The value of the mean bottom slope inclination is also very high and amounts to 0.47 \pm 0.21 ; $\mathrm{Me}=0.35$, which means that the bottom slope angle varies from $27^{\circ}$ to $45^{\circ}$. Right next to the shore (peatland) the walls descend vertically, whereas in the katotelm, in the places where water pockets form, the walls can be at an angle of more than $90^{\circ}$.

Lakes located on outwash plains, in comparison with the moraine-dammed lakes, have a four times bigger area $(1,25 \pm 1,17$ ha; $\mathrm{Me}=1,0)$. However, small lakes can also be found ( $<0.3$ ha; Fig. 7$)$. Peatlands are a little bigger than the lakes $(1.75 \pm 1.14 \mathrm{ha}$; $\mathrm{Me}=1.43)$, but Ohle (4.2 $\pm 6.3 ; \mathrm{Me}=1.5)$ and Schindler coefficients have three times lower values, which indicates that the lakes are more resistant to the effect of peatlands. What is more, they are distinctly elongated $(1.69 \pm 0.38$; $\mathrm{p}=0.047)$ due to a substantial difference between their maximum length and breadth $(146 \pm 82 \mathrm{~m}$ and 89 

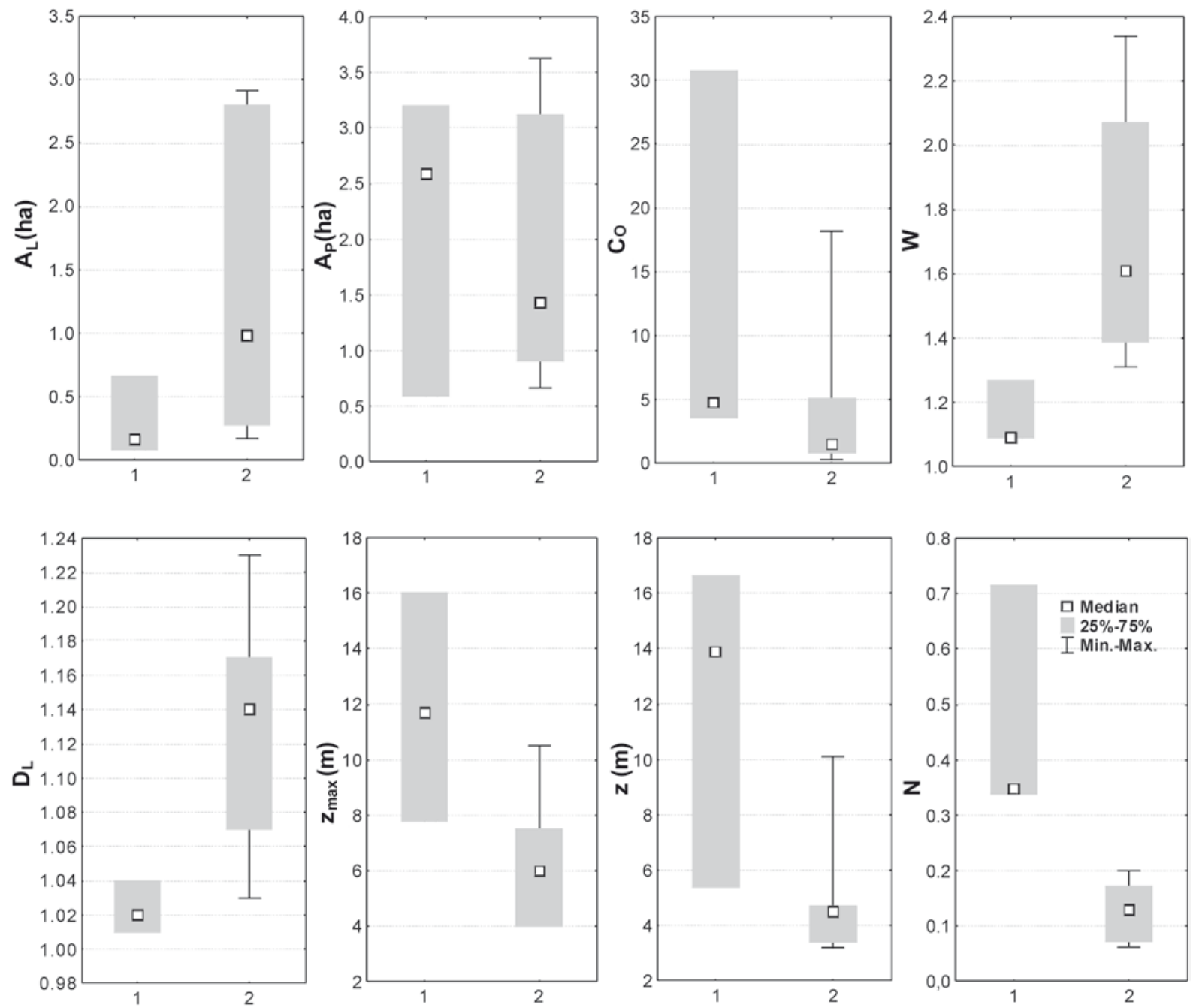

Fig. 7. Features and morphometric coefficients of lakes situated in moraine areas (1) and on outwash plains (2)

$\pm 49 \mathrm{~m}$, respectively), as well as a higher, but still very low, coefficient of shoreline development $(1.13 \pm 0.07$; $\mathrm{Me}=1.14 ; \mathrm{p}=0.04)$. The maximum depth of outwash lakes $(6.0 \pm 2.4 \mathrm{~m} ; \mathrm{Me}=6.0)$ is almost twice as shallow as that of moraine-dammed lakes ( $\mathrm{p}=0.02$; Fig. 7 ). The coefficient of basin concavity is similar and very high (145.4 $\pm 37.5 ; \mathrm{Me}=138)$. The mean bottom slope inclination is four times smaller $(0.12 \pm 0.05 ; \mathrm{p}=0.003)$. The variation range of lake volume and bottom area is wide: $5,743-132,519 \mathrm{~m}^{3}$ and 1,791-29,317 $\mathrm{m}^{2}$.

The differences between lakes from moraine areas and outwash plains are statistically significant especially for the features connected with depth $\left(z_{\max }\right.$, $\mathrm{z}, \mathrm{z}_{\mathrm{r}}$ ) and bottom slope inclination $(\mathrm{N})$. The values of these features are decidedly higher for morainedammed water bodies. It is worth mentioning, though, that deep peatland lakes with steeply inclined walls, whose catchment slopes have been shaped by river erosion, can also be found on outwash plains.

\section{Discussion}

In lake-mire complexes, lake features are dependent on the processes taking place in peatlands. If a deep peatland lake overgrows, then the features of its basin and aquatic environment are retained for a relatively long time. The morphometric peculiarity of such lakes consists of a purely organic bottom with a very varied slope inclination. These are mainly small lakes with an area of up to $1 \mathrm{ha}$, which is generally included in catalogues of lakes (Choiński 2006). The small area and volume of such water bodies make them highly 
susceptible to the effect of peatlands. On the one hand, the peatlands isolate them from the inflows from their catchments. However, that said, they contribute to the one-sided development of these lakes influenced by the features of peat deposits. Although, it should be emphasized that, among raised bogs themselves, there are substantial differences in the properties of water deposited in peat. This depends, above all, on the development stage of vegetation and level of peat desiccation (Gorham et al. 1986; Engstrom 1987; Banaś 1999; Banaś and Gos 2004).

The shallowest sections of the littoral zone in peatland lakes are covered with a floating mat under which there are vertical peat walls rarely occupied by submerged plants (Banaś and Gos 2008). Deeper, water 'pockets' of various sizes are always found. Plants do not occur in such pockets because of the shortage of light and intensive filling with peat coming from the katotelm. The deepest parts of lake basins are flat and can be occupied but this is possible only in shallow water bodies. Peatland lake waters are rich in humic substances, which cause high light extinction (Nielsen and Ekelund 1993; Frimmel 1994; Schindler et al. 1996) and limit the occurrence of submerged plants in the deepest zones of the littoral (Bociąg 2000).
In peatland lakes, the development of submerged vegetation is limited by the neighbouring peatlands, whereas in other equally small lakes, whose bottom resembles a bowl (see Fig. 4), such a limiting factor does not occur. As a result, in small lakes which are not located in peatlands the surface that can be occupied by submerged plants is relatively big. In general, peatland lake basins are deeper than in other equally small water bodies (see Fig. 4). With such arrangement of the bottom topography, there are very few places potentially able to be occupied (Banaś and Gos 2008). Above all, there is a lack of places for vascular plants which anchor themselves in the substrate. In peatland lakes, there are acidic, organic, and highly hydrated sediments which limit the occurrence of aquatic plants and lead to changes in vegetation structure (Roelofs 1983; Grahn 1985; Arts 1987; Szmeja $1994 a, b, c)$. The presence of such sediments results in the replacement of basiphilous and neutrophilous species with acidophilous ones, mainly bryophytes (Szmeja 1992, 2000; Bociąg 2000).

Two models of peatland lake basins were distinguished (Fig. 8). The first one is typical of big but shallow lakes with substantial volume. Such lakes occur on outwash plains and are characterized by low
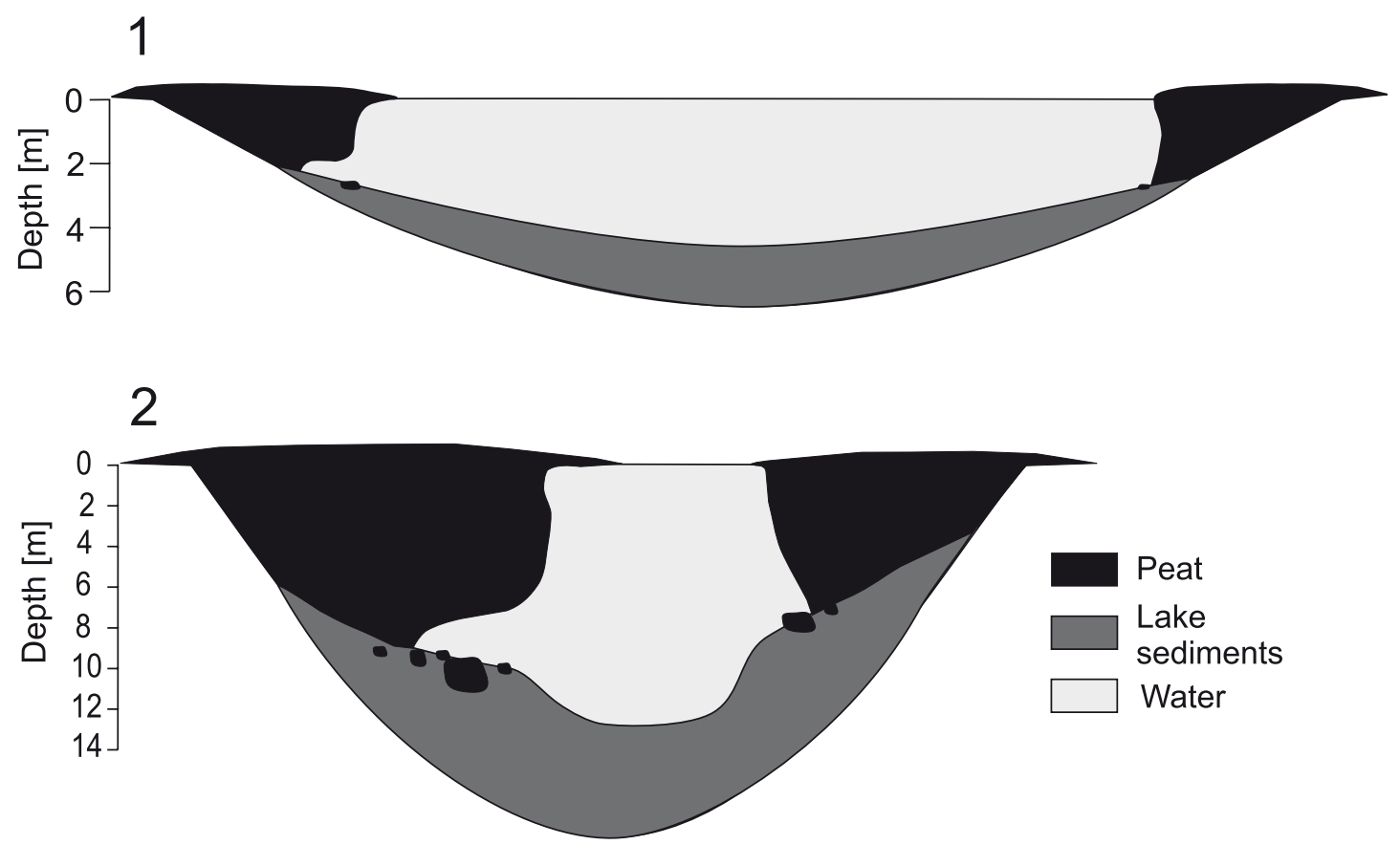

Fig. 8. Graphic models of peatland lake basins: 1 - basins of big lakes with high volume and small contact area with the peat deposit, 2 - basins of small lakes with small volume and big contact area with the peat deposit 
peat walls and small water pockets in the katotelm. In addition, their floating mat is poorly developed. The second model is characteristic of small but deep water bodies with small volume. They mainly occur in moraine areas. Their high vertical walls consist of peat deposits and the water pockets under the katotelm have substantial capacity. The floating mat is fully developed. The big peatland area and small lake volume make such lakes susceptible to the effect of acid and strongly coloured peatland waters rich in organic matter (Banaś and Gos 2004).

The presented models are stages in the transformation of acid oligotrophic lakes towards raised bogs. According to Tobolski (2003), more than half of peatlands in NW Poland were formed in this way. It should be noted; however, that the overgrowth process in peatland lakes is very slow (Kowalewski and Tobolski 1997; Timmermann 1998). This is probably due to the fact that it is not the floating mat that determines the overgrowth rate but the slow formation of peat deposits in the katotelm. Deep lakes overgrow longer than shallow ones, as in deep lakes a thicker peat deposit visible under water in the form of high walls is needed. Clods of peat break off the vertical walls of peat deposits, fall to the bottom of the water body, and disturb the structure and stratigraphy of limnic sediments.

The floating mat is especially well developed in small and deep water bodies where water mixing rates are very low. In favourable environmental conditions the floating mat forms only a 3-meter broad belt. In my opinion, the floating mat can be a significant cause of lake overgrowth only in the terminal phase of this process. What is more, in winter, outer fragments of the floating mat are often broken off (Timmermann and Succow 2001) or destroyed by islands floating on a lake. Some edge fragments of the floating mat fall down to the bottom under the weight of vigorously developing bryophytes. Such a situation occurs when there are no vascular plants on the edge of the floating mat, as their rhizomes and roots would otherwise strengthen this structure (Tobolski 2003; Banaś and Gos 2008).

The presented models, especially the second one (Fig. $8-2$ ), emphasise the morphometric peculiarity of peatland lakes in comparison with other water bodies (Major 2008). They also reveal their regional variation. The first model dominates on outwash plains, while the second one in moraine areas. It is worth mentioning that in both cases the peat deposit isolates peatland lakes from the influence of the surrounding catchments. In the conditions of complete isolation and when water bodies are not fed with subterranean waters, the physical and chemical water properties in lakes can be similar to the properties of the water trapped in the peat deposit.

\section{Acknowledgements}

The author would like to thank Professor J. Szmeja for helpful comments made while this paper was being written, K. Gos, PhD, and M. Merdalski, MSc, for their help in field work. The study was conducted within the framework of the project KBN 2 PO4 G 06627.

\section{References}

Arts G.H.P., 1987, Historical development and extent of acidification of shallow soft waters in the Netherlands [in]: P. Mathy (ed.), Air pollution and ecosystems, Proc. Int. Symp., Grenoble: 928-933.

Banaś K., 1999, Osuszanie siedlisk organogenicznych a funkcjonowanie ekosystemów jeziornych (Drainage of the organogenic habitats and functioning of lake ecosystems), [in]: A. Barcikowski, M. Boiński, A. Nienartowicz (eds), Wielofunkcyjna rola lasu, ochrona przyrody, gospodarka, edukacja (Versatile role of forest, protection of nature, economy, education), O. W. Turpress, Toruń: 191-199 (in Polish).

Banaś K., Gos K., 1998, Transformacja roślinności podwodnej w procesie acydyfikacji jezior oligotroficznych na Pomorzu (Transformation of submerged vegetation in the process of acidification of oligotrophic lakes in Pomerania), [in]: W. Lange, D. Borowiak (eds), Zagrożenia degradacyjne a ochrona jezior (Degradation hazards and lakes' protection), Wyd. DJ, Gdańsk: 161-171 (in Polish).

Banaś K., Gos K., 2004, Effect of peat-bog reclamation on the physico-chemical characteristics of the water in peat, Pol. J. Ecol. 52(1): 69-74.

Banaś K., Gos K., 2008, Features and diversity of pomeranian peatland lakes, [in:] E. Bajkiewicz-Grabowska, D. Borowiak (eds), Anthropogenic and natural transformations of lakes. Vol. 2., Wyd. KLUG-PTLim, Gdańsk: 13-17.

Bociąg K., 2000, Transformacja roślinności podwodnej w procesie humizacji jezior (Transformation of submerged vegetation in the process of humification of lakes), Uniwersytet Gdański, Wydz. BGiO, Gdańsk, p. 167 (dissertation) (in Polish).

Choiński A., 2006, Katalog jezior Polski (Catalogue of Polish lakes), Wyd. Nauk. UAM, Poznań, p. 600 (in Polish).

Engstrom D.R., 1987, Influence of vegetation and hydrology on the humus budgets of Labrador lakes, Can. J. Fish. Aquat. Sci. 44: 1306-1314. 
Frimmel F.H., 1994, Photochemical aspects related to humic substances, Environ. Intern. 20: 373-386.

Gorham E., Underwood J.K., Martin F.B., Ogden J.G., 1986, Natural and anthropogenic causes of lake acidification in Nova Scotia, Nature 324: 451-453.

Gos K., Banaś K., 1999, Succession trends of submerged vegetation in Pomeranian acidic lakes (NW Poland), Acta Hyrobiol. 41, Suppl. 6: 171-178.

Gos K., Bociąg K., Banaś K., 1998, Roślinność podwodna w kwaśnych jeziorach Pomorza (Submerged vegetation in the acid lakes of Pomerania), [in:] J. Banaszak, K. Tobolski (eds), Park Narodowy Bory Tucholskie (Tuchola Forests National Park), Wyd. WSP, Bydgoszcz: 261-277 (in Polish).

Grahn O., 1985, Macrophyte biomass and production in Lake Gárdsjön - an acidified clearwater lake in SW Sweden, Ecol. Bull. 37: 203-221.

Hays W.L., 1988, Statistics ( $3^{\text {rd }}$ ed.), Holt, Rinehart and Winston, New York, p. 723.

Hutchinson G.E., 1957, A treatise on limnology. I. Geography, physics and chemistry, John Wiley \& Sons, New York, p. 1015.

Kajak Z., 1998, Hydrobiologia - limnologia (Hydrobiology limnology), Wyd. Nauk. PWN, Warszawa, p. 355 (in Polish).

Kowalewski G., 2003, Shoreline changes of basins in the mire-lake reserves in S Tuchola Pinewood, Limnol. Rev. 3: 119-126.

Kowalewski G., Milecka K., 2003, Palaeoecology of basins of organic sediment accumulation in the Reserve Dury, Studia Quaternaia 20: 73-82.

Kowalewski G., Tobolski K., 1997, Teledetekcyjna analiza zmian w obrębie rezerwatu "Bagno Stawek" (Teledetection analysis of changes in grounds of reserve „Bagno Stawek”), [in:] E. Krasicka-Korczyńska (ed.), Ochrona gatunkowa na obszarach chronionych (Species protection on protected areas), Towarzystwo Miłośników Borów Tucholskich: 71-79 (in Polish).

Lange W. (ed.), 1993, Metody badań fizycznolimnologicznych (Physicolimnological methods of study), Wyd. UG, Gdańsk, p.175 (in Polish).

Major M., 2008, Morphometric differences among basins without outlets in the southern and central parts of the Parseta catchment. Limnol. Rev. 8(1-2): 43-49.

Nielsen T., Ekelund N.G.A., 1993, Effect of UV-B radiation and humic substances on growth and motility of Gyrodinium aureolum, Limnol. Oceanogr. 38(7): 1570-1575.

Roelofs J.G.M., 1983, Impact of acidification and eutrophication on macrophyte communities in soft waters in the Netherlands. I. Field observations, Aquatic Bot. 17: 139155.
Schindler D.W., Curtis P.J., Parker B.R., Stainton M.P., 1996, Consequences of climate warming and lake acidification for UV-B penetration in North American boreal lakes, Nature 379: 705-708.

Shotyk W., 1988, Review of the inorganic geochemistry of peat and peatland waters, Earth-Sci. Rev. 25: 95-176.

Szmeja J., 1992, Struktura, organizacja przestrzenna i demografia populacji isoetydów. Studium ekologiczne roślin podwodnych (Structure, spatial organization and demography of isoetid populations. Ecological studies of submerged aquatic plants), Zesz. Naul. UG, Rozpr. Monogr. 175, Gdańsk, p.137 (in Polish).

Szmeja J., 1994a, An individual's status in populations of isoetid species, Aquatic Bot. 48: 203-224.

Szmeja J., 1994b, Effect of disturbances and interspecific competition in isoetid populations, Aquatic Bot. 48: 225-238.

Szmeja J., 1994c, Dynamics of the abundance and spatial organisation of isoetid populations in an oligotrophic lake, Aquatic Bot. 49: 19-32.

Szmeja J., 2000, Tendences of changes in the flora and vegetation structure of Pomeranian lakes under the influence of humic substances, [in:] B. Jackowiak, W. Żukowski (eds), Mechanisms of anthropogenic changes of the plant cover, Bogucki Wyd. Nauk., Poznań: 85-98.

Szmeja J., Banaś K., Bociąg K., 1997, Ecological conditions and tolerance limits of isoetids along the southern Baltic coast, Ekol. Pol. 45(2): 343-359.

Ter Braak C.J.F., Smilauer P., 1998, CANOCO Reference Manual and User's Guide to Canoco for Windows: Software for Canonical Community Ordination (version 4), Microcomputer Power, New York: p. 352.

Timmermann T., 1998, Die Moorforschung Kurt Huecks - ihre Bedeutung damals und heute, Verh. Bot. Berlin. Brandenburg 131: 37-51.

Timmermann T., Succow M., 2001, Kesselmoore, [in:] M. Succow, H. Joosten (eds), Landschaftsökologische Moorkunde, E. Schweizerbart'sche Verlagsbuchhandlung, Stuttgart: 379-390.

Tobolski K., 2000, Przewodnik do oznaczania torfów i osadów jeziornych (Guidebook to marking peats and lake sediments), [in:] J. Faliński (ed.), Vademecum Geobotanicum, Wyd. Naukowe PWN. Warszawa, p. 506 (in Polish).

Tobolski K., 2003, Torfowiska na przykładzie ziemi Świeckiej (Peatland on example of the Swiecka ground), Tow. Przyjaciół Dolnej Wisły, Świecie, p. 255 (in Polish).

Turczyński M., Sobolewski W., Mięsiak-Wójcik K., 2009, Selected problems related to the demarcation of lake range in the light of field surveys, Limnol. Rev. 9(4): 203 -214.

Wetzel R.G., 2001, Limnology: Lake and River Ecosystems, 3rd edition, Elsevier Academic Press, San Diego, p. 1006. 